\title{
Correction to: Selection of suitable predatory mites against, Panonychus citri (McGregor) (Acari: Tetranychidae) using relative control potential metrics and functional response
}

\author{
Muhammad Asif Qayyoum ${ }^{1 *}$ (D), Zi-Wei Song ${ }^{1}$, Bilal Saeed Khan², Muhammad Irfan Akram³, \\ Muhammad Zeeshan Shabbir ${ }^{1}$, Izhar Hussain ${ }^{4}$, Bao-Xin Zhang ${ }^{1}$, Yuan Zheng ${ }^{1}$ and Dun-Song Li ${ }^{1}$
}

\section{Correction to: Egypt J Biol Pest Control (2021) 31:143} https://doi.org/10.1186/s41938-021-00489-0 Following publication of article [1], the authors flagged the following two errors in the affiliations information: Muhammad Irfan Akram had been incorrectly assigned affiliation 4 instead of 3; Izhar Hussain had been incorrectly assigned affiliation 3 instead of 4 .

The affiliation information has since been corrected in the published article.

\begin{abstract}
Author details
${ }^{1}$ Plant Protection Research Institute, Guangdong Academy of Agricultural Sciences, 7 Jinying Road, Tianhe District, Guangzhou 510640, China. ${ }^{2}$ Department of Entomology, Faculty of Agriculture, University of Agriculture, Faisalabad 38040, Punjab, Pakistan. ${ }^{3}$ Department of Entomology, Faculty of Agriculture and Environment, The Islamia University of Bahawalpur, Bahawalpur 63100, Punjab, Pakistan. ${ }^{4}$ Department of Plant Breeding and Genetics, University of Haripur, Haripur, KPK, Pakistan.
\end{abstract}

Published online: 03 March 2022

\section{Publisher's Note}

Springer Nature remains neutral with regard to jurisdictional claims in published maps and institutional affiliations.

\footnotetext{
*Correspondence: asifqayyoum@gmail.com

1 Plant Protection Research Institute, Guangdong Academy of Agricultural

Sciences, 7 Jinying Road, Tianhe District, Guangzhou 510640, China
}

Full list of author information is available at the end of the article

\section{Springer Open}

(c) The Author(s) 2022. Open Access This article is licensed under a Creative Commons Attribution 4.0 International License, which permits use, sharing, adaptation, distribution and reproduction in any medium or format, as long as you give appropriate credit to the original author(s) and the source, provide a link to the Creative Commons licence, and indicate if changes were made. The images or other third party material in this article are included in the article's Creative Commons licence, unless indicated otherwise in a credit line to the material. If material is not included in the article's Creative Commons licence and your intended use is not permitted by statutory regulation or exceeds the permitted use, you will need to obtain permission directly from the copyright holder. To view a copy of this licence, visit http://creativecommons.org/licenses/by/4.0/. 